\title{
Purinergic receptors are part of a signalling system for proliferation and differentiation in distinct cell lineages in human anagen hair follicles
}

\author{
Aina V. H. Greig • Claire Linge • Geoffrey Burnstock \\ Received: 5 March 2008 / Accepted: 17 April 2008 / Published online: 27 May 2008 \\ (C) Springer Science + Business Media B.V. 2008
}

\begin{abstract}
We investigated the expression of $\mathrm{P}_{2} \mathrm{X}_{5}, \mathrm{P} 2 \mathrm{X}_{7}$, $\mathrm{P} 2 \mathrm{Y}_{1}$ and $\mathrm{P} 2 \mathrm{Y}_{2}$ receptor subtypes in adult human anagen hair follicles and in relation to markers of proliferation [proliferating cell nuclear antigen (PCNA) and Ki-67], keratinocyte differentiation (involucrin) and apoptosis (anticaspase-3). Using immunohistochemistry, we showed that $\mathrm{P} 2 \mathrm{X}_{5}, \mathrm{P} 2 \mathrm{Y}_{1}$ and $\mathrm{P} 2 \mathrm{Y}_{2}$ receptors were expressed in spatially distinct zones of the anagen hair follicle: $\mathrm{P} 2 \mathrm{Y}_{1}$ receptors in the outer root sheath and bulb, $\mathrm{P} 2 \mathrm{X}_{5}$ receptors in the inner and outer root sheaths and medulla and $\mathrm{P} 2 \mathrm{Y}_{2}$ receptors in living cells at the edge of the cortex/medulla. $\mathrm{P}_{2} \mathrm{X}_{7}$ receptors were not expressed. Colocalisation experiments suggested different functional roles for these receptors: $\mathrm{P}_{2} \mathrm{Y}_{1}$ receptors were associated with bulb and outer root sheath keratinocyte proliferation, $\mathrm{P} 2 \mathrm{X}_{5}$ receptors were associated with differentiation of cells of the medulla and inner root sheaths and $\mathrm{P} 2 \mathrm{Y}_{2}$ receptors were associated with early differentiated cells in the cortex/medulla that contribute to the formation of the hair shaft. The therapeutic potential of purinergic agonists and antagonists for controlling hair growth is discussed.
\end{abstract}

\footnotetext{
A. V. H. Greig · G. Burnstock $(\bowtie)$

Autonomic Neuroscience Centre,

Royal Free and University College Medical School,

Rowland Hill Street,

London NW3 2PF, UK

e-mail: g.burnstock@ucl.ac.uk

C. Linge

RAFT Institute of Plastic Surgery, Mount Vernon Hospital, Leopold Muller Building, Northwood,

Middlesex HA6 2RN, UK
}

Keywords Receptors · Purinergic · Hair follicle · Proliferation · Differentiation

$\begin{array}{ll}\text { Abbreviations } \\ \text { AA } & \text { amino acids } \\ \text { ATP } & \text { adenosine 5'-triphosphate } \\ \text { ADP } & \text { adenosine 5'-diphosphate } \\ \text { DAB } & \text { diaminobenzidine } \\ \text { NGS } & \text { normal goat serum } \\ \text { NHS } & \text { normal horse serum } \\ \text { IRS } & \text { inner root sheath } \\ \text { ORS } & \text { outer root sheath } \\ \text { PBS } & \text { phosphate buffered saline } \\ \text { PCNA } & \text { proliferating cell nuclear antigen }\end{array}$

\section{Introduction}

The cells of the lower portion of the hair follicle bulb are undifferentiated matrix cells. These are rapidly dividing cells that give rise to eight different cell lineages [1]. From within outwards, these include the medulla, cortex and hair cuticle cell lineages that make up the hair shaft; the inner root sheath cuticle, Huxley's and Henle's layers that make up the inner root sheath (IRS); and the companion layer and the outer root sheath (ORS) [1]. The hair cycle is divided into periods of hair growth (anagen), which are followed by a regression phase (catagen), when the lower part of the hair follicle undergoes programmed cell death [2], and a resting phase (telogen), before onset of a new growth phase.

The growing anagen hair follicle is an attractive system for studying proliferation and differentiation. There is increasing evidence that purinergic signalling can have long-term, 
trophic effects on these processes [3, 4]. Adenosine 5'triphosphate (ATP) is now recognised as an important messenger molecule for cell-cell communication, with ATP binding specifically to purinergic receptors $[5,6]$. Purinergic receptors are classified into two groups: P1 receptors are selective for adenosine, and $\mathrm{P} 2$ receptors are selective for ATP and adenosine 5'-diphosphate (ADP), which act as extracellular signalling molecules [6]. P2 receptors are divided into two main families: P2X receptors, which are ligand-gated ion channels, and P2Y receptors, which are G proteincoupled, based on molecular structure, transduction mechanisms and pharmacological properties [7]. Seven subtypes of $\mathrm{P} 2 \mathrm{X}$ receptors [8] and eight subtypes of $\mathrm{P} 2 \mathrm{Y}$ receptors are recognised [9]. There is growing evidence that ATP may act as an important local messenger in the epidermis. Purinergic receptors are expressed on rat cutaneous keratinocytes, and functional roles in the regulation of proliferation, differentiation and cell death have been proposed [10]. In particular, $\mathrm{P}_{2} \mathrm{X}_{5}$ receptors are expressed on cells undergoing proliferation and differentiation, whereas $\mathrm{P}_{2} \mathrm{X}_{7}$ receptors are associated with keratinised dead cells. $\mathrm{P}_{2} \mathrm{Y}_{2}$ receptors, found in the basal layer of normal epidermis, are claimed to be involved in keratinocyte proliferation [11]. $\mathrm{P}_{2} \mathrm{Y}_{1}$ receptors are thought to be mitogenic in endothelial cells [4]. Previous work on adult human interfollicular epidermis and primary keratinocyte cultures has suggested that $\mathrm{P}_{2} \mathrm{Y}_{1}$ and $\mathrm{P}_{2} \mathrm{Y}_{2}$ receptors are involved in keratinocyte proliferation and that $\mathrm{P} 2 \mathrm{X}_{5}$ receptors are likely to be involved in keratinocyte differentiation, whereas $\mathrm{P} 2 \mathrm{X}_{7}$ receptors are likely to be part of the machinery of end-stage terminal differentiation of keratinocytes [12].

This study demonstrates for the first time the distribution of P2X and P2Y receptors in human anagen hair follicles. We propose that these receptors are part of the normal homeostatic mechanisms controlling hair keratinocyte proliferation and differentiation.

\section{Materials and methods}

\section{Tissues}

Eight samples of normal hair-bearing human skin were examined immunohistochemically in this study. Ethical Committee approval was obtained to harvest human skin. Samples of postoperatively redundant skin from otoplasty, preauricular skin tags and from the leg were obtained. Tissue was frozen in isopentane precooled in liquid nitrogen to cryoprotect the tissue and prevent damage to the tissue architecture from ice crystals. Blocks were sectioned at 10 $\mu \mathrm{m}$ on a cryostat (Reichert Jung CM1800), collected on gelatine-coated slides and air-dried at room temperature. The slides were stored at $-20^{\circ} \mathrm{C}$.

\section{Antibodies}

The immunogens used to produce polyclonal $\mathrm{P} 2 \mathrm{X}_{5}$ and $\mathrm{P}_{2} \mathrm{X}_{7}$ antibodies were synthetic peptides corresponding to 15 receptor-type-specific amino acids (AA) in the intracellular $\mathrm{C}$ termini of the cloned rat and human $\mathrm{P} 2 \mathrm{X}$ receptors, as previously described $[10,13]$. $\mathrm{P} 2 \mathrm{X}_{5}$ and $\mathrm{P} 2 \mathrm{X}_{7}$ antibodies (provided by Roche Bioscience, Palo Alto, CA, USA) were kept frozen at a stock concentration of $1 \mathrm{mg} / \mathrm{ml}$. Polyclonal anti-P2 $\mathrm{Y}_{1}$ and $\mathrm{P} 2 \mathrm{Y}_{2}$ antibodies were obtained from Alomone Labs (Jerusalem, Israel) and corresponded to the third extracellular loop of the $\mathrm{P}_{2} \mathrm{Y}_{1}$ (AA 242-258) and $\mathrm{P}_{2} \mathrm{Y}_{2}$ receptor (AA 227-244). Antibodies were kept frozen at a stock concentration of $0.6 \mathrm{mg} / \mathrm{ml}\left(\mathrm{P}_{2} \mathrm{Y}_{1}, \mathrm{P}_{2} \mathrm{Y}_{2}\right)$. Proliferating cell nuclear antigen (PCNA) is a marker for proliferation in normal adult human keratinocytes [14]. Involucrin is a marker for keratinocyte differentiation [15]. PCNA (monoclonal antiproliferating cell nuclear antigen, clone PC10, raised in mouse ascites fluid; Sigma Chemical Co., Poole, UK) and involucrin (Sigma) antibodies were raised in the mouse. Ki-67 antigen is a marker for cell proliferation in normal human keratinocytes [16, 17]. Active caspase-3 is part of the apoptotic machinery of the cell and is expressed in terminally differentiating keratinocytes [18]. Ki-67 (DAKO, Heverlee, Denmark) and active caspase-3 (Abcam, Cambridge, UK) antibodies were both raised in the rabbit.

\section{Immunohistochemistry}

For immunostaining of cryostat sections, the avidin-biotin technique was used according to a revised protocol [19, 20]. Air-dried sections were fixed for $2 \mathrm{~min}$ in $4 \%$ formaldehyde in $0.1 \mathrm{M}$ phosphate buffer containing $0.2 \%$ of a saturated solution of picric acid $(\mathrm{pH}$ 7.4). Fixation was carried out at this point, as earlier fixation of the entire tissue can result in alteration of the antibody binding sites, interfering with staining. Endogenous peroxidase was blocked for 10 min with $50 \%$ methanol containing $0.4 \%$ hydrogen peroxide. Nonspecific binding sites were blocked by a 20 -min preincubation in $10 \%$ normal horse serum (NHS) in $0.1 \mathrm{M}$ phosphate buffer containing $0.05 \%$ merthiolate (Sigma), followed by incubation with the primary antibodies diluted to $1: 100$ or $1: 200$ in antibody diluent $[10 \%$ NHS in PBS $+2.5 \%$ sodium chloride $(\mathrm{NaCl})]$ at $4^{\circ} \mathrm{C}$ overnight. Subsequently, the sections were incubated with biotinylated donkey anti-rabbit immunoglobulin G (IgG) (Jackson ImmunoResearch Lab, West Grove, PA, USA) diluted to 1:500 in $1 \%$ NHS in PBS for $30 \mathrm{~min}$, followed by ExtrAvidin peroxidase conjugate (Sigma) diluted to 1:1000 in PBS for $30 \mathrm{~min}$ at room temperature. After a wash step, a nickeldiaminobenzidine (DAB) enhancement technique was used to visualise the reaction product. Sections were washed three 
times with PBS after each of the above steps except for after preincubation with $10 \%$ NHS. After the last wash, sections were dehydrated twice in isopropanol and mounted with EUKITT (BDH Laboratory Supplies, Poole, UK). Control experiments were carried out with primary antibodies omitted from the staining procedure or the primary antibodies preabsorbed with the corresponding peptides.

\section{Double labelling of $P 2 X$ or $P 2 Y$ receptor antibodies with either PCNA or involucrin}

Sections were fixed and incubated with $\mathrm{P} 2 \mathrm{X}$ or $\mathrm{P} 2 \mathrm{Y}$ antibodies overnight, as described above. After a wash step, biotinylated donkey anti-rabbit $\operatorname{IgG}$ antibody, diluted 1:500 in $1 \%$ NHS in PBS, was then applied for $1 \mathrm{~h}$, followed by Streptavidin Texas red (Amersham Plc., Little Chalfont, UK), diluted 1:200 in PBS-merthiolate for $1 \mathrm{~h}$ at room temperature. Sections were preincubated for $30 \mathrm{~min}$ with $10 \%$ normal goat serum (NGS) diluted in $0.1 \mathrm{M}$ phosphate buffer containing $0.05 \%$ merthiolate (Sigma). They were then incubated for $2 \mathrm{~h}$ at room temperature with one of the following antibodies: PCNA antibody (Sigma) diluted 1:1000; mouse monoclonal anti-involucrin (Sigma) diluted 1:50. After a wash step, the directly labelled secondary antibody goat anti-mouse FITC (Nordic Immunological Laboratories, Tilburg, The Netherlands) was applied at a dilution of 1:200 for $1 \mathrm{~h}$, and sections were washed and mounted in Citifluor (Citifluor Ltd., Leicester, UK). P2X or P2Y receptor immunostaining appeared red and PCNA and involucrin stained green.

\section{Double-labelling of $P 2 X$ or $P 2 Y$ receptor antibodies with either Ki-67 antigen or anti-human caspase-3}

Sections were fixed and incubated with $\mathrm{P} 2 \mathrm{X}$ or $\mathrm{P} 2 \mathrm{Y}$ antibodies overnight, as described above. After washing, sections were incubated with biotinylated donkey antirabbit IgG (Jackson) diluted to $1: 500$ in 1\% NHS in PBS for $1 \mathrm{~h}$, followed by ExtrAvidin peroxidase conjugate (Sigma) diluted to 1:1500 in PBS for $1 \mathrm{~h}$, tyramide amplification for 8 min (Tyramide Amplification Kit, NEN Life Science Products, Boston, MA, USA) and then Streptavidin Texas red (Amersham), diluted 1:200 in PBS-merthiolate for $10 \mathrm{~min}$. Sections were washed three times in PBS after each of the above steps. Sections were preincubated for $20 \mathrm{~min}$ in $10 \%$ NGS and incubated at room temperature for $2 \mathrm{~h}$ with one of the following antibodies: rabbit anti-human Ki-67 antigen (DAKO) 1:50 or rabbit anti-human active caspase-3 (Abcam). Sections were washed and incubated with the directly labelled secondary antibody Oregon-green-labelled goat anti-rabbit IgG (Jackson) diluted 1:100 for $45 \mathrm{~min}$. Sections were then washed and mounted in Citifluor (Citifluor). P2X or P2Y receptor immunostaining appeared red; Ki-67 and caspase-3 stained green.

\section{Photography}

The results were photographed using a Zeiss Axioplan high-definition light microscope (Oberkochen, Germany) mounted with a Leica DC 200 digital camera (Heerbrugg, Switzerland).

\section{Results}

Only hair follicles in the anagen (growth) phase were studied, as hair follicles in catagen (regression) or telogen (resting) phases of the hair cycle were not seen in the sections analysed.

$\mathrm{P} 2 \mathrm{X}_{5}, \mathrm{P} 2 \mathrm{X}_{7}, \mathrm{P}_{2} \mathrm{Y}_{1}$ and $\mathrm{P} 2 \mathrm{Y}_{2}$ receptors are expressed in human anagen hair follicles

$\mathrm{P} 2 \mathrm{X}_{5}$ receptor immunoreactivity was observed in the hair keratinocytes of all human skin samples. $\mathrm{P}_{2} \mathrm{X}_{5}$ receptor staining was restricted to the medulla and both the IRS and ORS (Fig. 1a,b), which were continuous with the surface epidermis. $\mathrm{P} 2 \mathrm{X}_{7}$ receptor immunostaining was present in the stratum corneum of the overlying epidermis, but there was no staining in the anagen hair follicle (Fig. 1c,d). P2 $Y_{1}$ receptors were found in the ORS and bulb of anagen hair follicles but not in the IRS (Fig. 2a,b). P2 $\mathrm{Y}_{2}$ receptors were found in cells in the cortex, with possibly a few positive cells at the edge of the medulla, but no staining in the central medulla (Fig. 2c,d).

Double labelling of $\mathrm{P} 2 \mathrm{Y}_{1}$ receptors with Ki-67 showed that $\mathrm{P} 2 \mathrm{Y}_{1}$ receptors were found in proliferating cells in the ORS and bulb of anagen hair follicles (Fig. 3a,b). Double labelling of $\mathrm{P}_{2} \mathrm{Y}_{2}$ receptors with PCNA showed that $\mathrm{P} 2 \mathrm{Y}_{2}$ receptors were expressed in the cortex and possibly at the edge of the medulla (Fig. 3c) and PCNA was expressed in the ORS and bulb (Fig. 3c,d). $\mathrm{P}_{2} \mathrm{Y}_{2}$ receptors were only expressed in viable cells and not in the keratinised hair shaft or the central medulla (Fig. 3d). Involucrin was expressed both in the cortex and IRS but not in the ORS (Fig. 3e,f). $\mathrm{P} 2 \mathrm{X}_{5}$ receptors were expressed in the medulla, IRS and ORS. There was colocalisation of involucrin with $\mathrm{P}_{2} \mathrm{X}_{5}$ receptor staining in the IRS and in a few cell layers at the edge of the medulla (Fig. 3e,f). Double labelling of $\mathrm{P}_{2} \mathrm{X}_{7}$ receptors with active caspase- 3 did not show any immunoreaction within the anagen hair follicle.

Control immunostaining experiments

Both omission of the primary antibody and preabsorption with corresponding peptides were performed as controls. The immunoreaction was abolished after preabsorption of the $\mathrm{P}_{2} \mathrm{X}_{5}$ (Fig. 1e), $\mathrm{P} 2 \mathrm{X}_{7}$ (Fig. 1f), $\mathrm{P}_{1} \mathrm{Y}_{1}$ (Fig. 2e) or P2Y 2 
Fig. 1 Expression of $\mathrm{P} 2 \mathrm{X}_{5}$ and
$\mathrm{P}_{2} \mathrm{X}_{7}$ receptors in human anagen

Fig. 1 Expression of $\mathrm{P} 2 \mathrm{X}_{5}$ and
$\mathrm{P}^{2} \mathrm{X}_{7}$ receptors in human anagen hair follicles. a Longitudinal section of anagen hair follicle. $\mathrm{P} 2 \mathrm{X}_{5}$ receptor immunostaining

was present in the outer root
sheath $(O R S)$ and medulla $(M)$
but not in the dermal papilla

was present in the outer root
sheath $(O R S)$ and medulla $(M)$
but not in the dermal papilla

was present in the outer root
sheath $(O R S)$ and medulla $(M)$
but not in the dermal papilla $(D P)$. Scale bar $=75 \mu \mathrm{m}$. b Transverse section of anagen hair follicle. $\mathrm{P} 2 \mathrm{X}_{5}$ receptor immunostaining was present in both the inner root sheath (IRS) and the outer root sheath (ORS) but not in the cortex $(C T X)$ or in the acellular medulla $(M)$ of the hair shaft at this level. Scale bar $=30 \mu \mathrm{m}$. c $\mathrm{P} 2 \mathrm{X}_{7}$ receptor immunostaining (arrow) was present in the stratum corneum. There was no immunoreaction in the anagen hair follicle. Scale bar $=75 \mu \mathrm{m}$. d P2X $\mathrm{X}_{7}$ receptor immunostaining, transverse section. There was no staining in the outer root sheath $(O R S)$, cortex $(C T X)$ or acellular medulla $(M)$ of the hair shaft at this level. Scale bar $=30 \mu \mathrm{m}$. e, f Controls: the immunoreaction was abolished after preabsorption of the e P2X $\mathrm{X}_{5}$ and $\mathbf{f} \mathrm{P} 2 \mathrm{X}_{7}$ receptor antibodies with the corresponding peptides, confirming the specificity of the immunoreaction. Scale bars $=100 \mu \mathrm{m}$ a

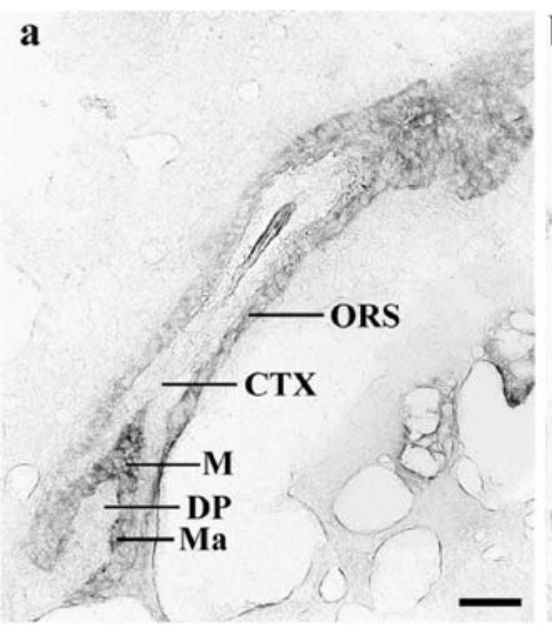

b

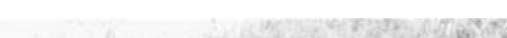

(n)

$+2$ (1)

(100

(n)
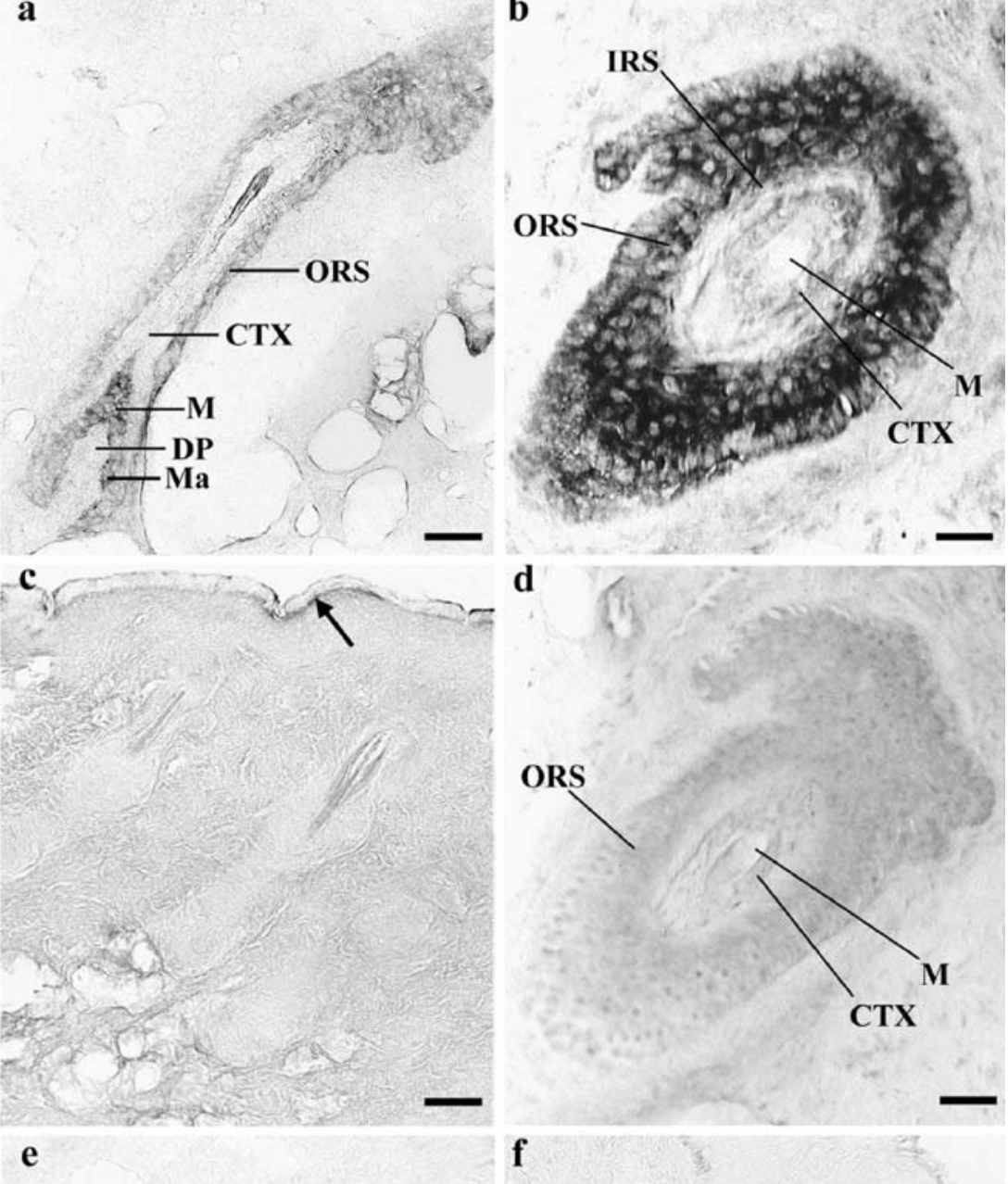

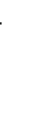


Fig. 2 Expression of $\mathrm{P} 2 \mathrm{Y}_{1}$ and $\mathrm{P} 2 \mathrm{Y}_{2}$ receptors in human anagen hair follicles. a $\mathrm{P} 2 \mathrm{Y}_{1}$ receptors were found in the outer root sheath $(O R S)$ and bulb of anagen hair follicles in longitudinal section but not in the inner root sheath (IRS). Scale bar $=40 \mu \mathrm{m}$. b In transverse section, $\mathrm{P} 2 \mathrm{Y}_{1}$ receptors were only seen in the outer root sheath (ORS). Scale bar $=40 \mu \mathrm{m}$. c $\mathrm{P}_{2} \mathrm{Y}_{2}$ receptors were found in the cortex $(C T X)$. Scale bar $=40 \mu \mathrm{m}$. d Transverse section of anagen hair follicle: $\mathrm{P}_{2} \mathrm{Y}_{2}$ receptors were seen in the cortex $(C T X)$ but not in the central medulla $(M)$, inner $(I R S)$ or outer root sheaths $(O R S)$, or in the surrounding adventitial layer $(A)$. Scale bar $=40 \mu \mathrm{m}$. e, $\mathbf{f}$ Controls: the immunoreaction was abolished after preabsorption of the e $\mathrm{P}_{2} \mathrm{Y}_{1}$ and $\mathbf{f} \mathrm{P}_{2} \mathrm{Y}_{2}$ receptor antibodies with the corresponding peptides, confirming the specificity of the immunoreaction. Scale bars $=100 \mu \mathrm{m}$
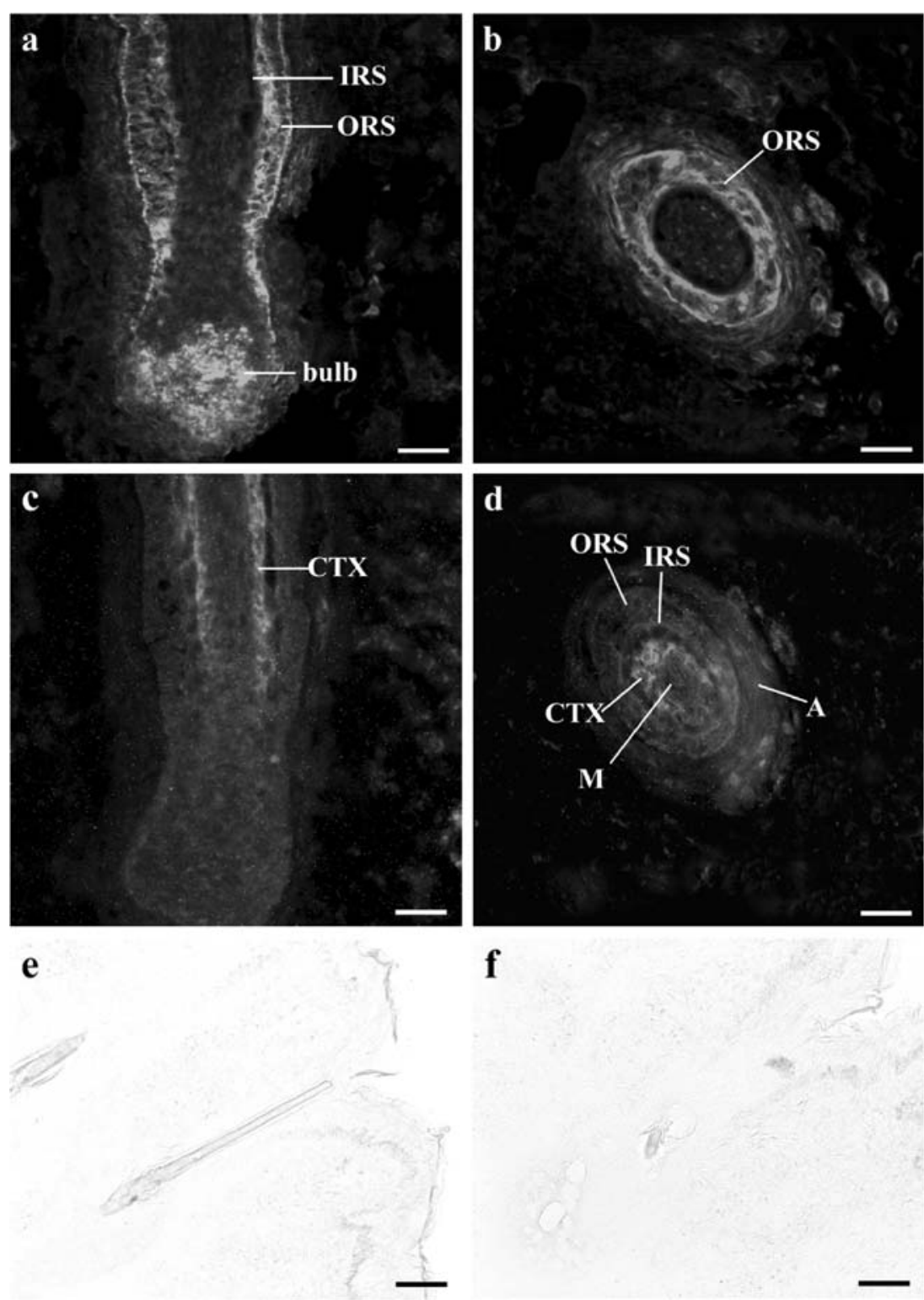

interfollicular epidermis confirmed the presence of $\mathrm{P}_{2} \mathrm{Y}_{1}$ receptors in proliferating cells [12]. The $\mathrm{P}_{2} \mathrm{Y}_{1}$ receptorselective agonist 2-methylthio ADP caused an increase in the number of human keratinocytes in vitro. It is therefore consistent that $\mathrm{P}_{2} \mathrm{Y}_{1}$ receptors would have a proliferative role in the anagen hair follicle ORS.

In anagen hair follicles, $\mathrm{P}_{2} \mathrm{Y}_{2}$ receptors were confined to a spatially distinct group of cells in the cortex and at the edge of the medulla, where there was no double labelling with proliferation markers. Commitment to the formation of the three hair shaft cell lineages (medulla, cortex, cuticle) takes place in a subcompartment of the hair matrix known as the precortex [1]. $\mathrm{P}_{2} \mathrm{Y}_{2}$ receptors seemed to be expressed on early differentiated cells in the hair shaft, because they were found on living cells of the cortex but not in the differentiated hair cuticle. Previous work on normal inter- follicular epidermis has shown that $\mathrm{P}_{2} \mathrm{Y}_{2}$ receptors are expressed in all cells of the basal layer and in a few cells within the stratum spinosum [12]. Stem cells in undamaged epidermis divide infrequently, and it is the nonstem daughters of stem cells, i.e. transit amplifying cells, which are actively dividing [1]. Double labelling of $\mathrm{P}_{2} \mathrm{Y}_{2}$ receptors with keratinocyte proliferation markers Ki-67 and PCNA in the interfollicular epidermis confirmed the presence of $\mathrm{P}_{2} \mathrm{Y}_{2}$ receptors in proliferating cells [12]. The $\mathrm{P}_{2} \mathrm{Y}_{2}$ receptor agonist uridine 5'-triphosphate also caused significant proliferation in keratinocytes [11, 12] and HaCaT keratinocytes [23]. $\mathrm{P}_{2} \mathrm{Y}_{2}$ receptors stained all the different cell populations within the basal layer of the epidermis (i.e. stem cells, transit amplifying cells and postmitotic cells). $\mathrm{P} 2 \mathrm{Y}_{2}$ receptors may then cause proliferation in transit-amplifying cells in the epidermis. Although 

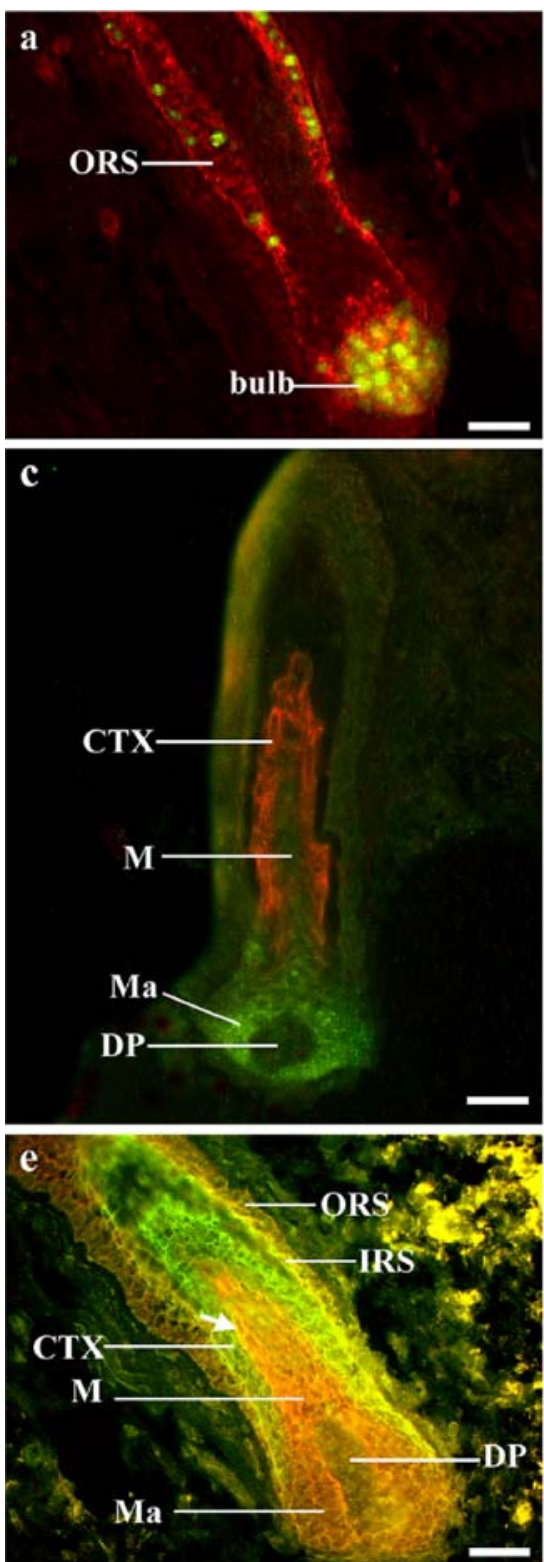

Fig. 3 Double labelling of $\mathrm{P}_{2} \mathrm{Y}_{1}$ and $\mathrm{P} 2 \mathrm{Y}_{2}$ receptors with markers for cellular proliferation, and double labelling of $\mathrm{P} 2 \mathrm{X}_{5}$ receptors with markers for keratinocyte differentiation in anagen hair follicles. a Double labelling of $\mathrm{P} 2 \mathrm{Y}_{1}$ receptors (red) with $\mathrm{Ki}-67$, a nuclear marker for proliferating cells (green), to show that $\mathrm{P}_{2} \mathrm{Y}_{1}$ receptors are found in proliferating basal cells in the outer root sheath $(O R S)$ and bulb region of the hair follicle in longitudinal section. Scale bar $=50 \mu \mathrm{m}$. $\mathbf{b}$ Transverse section: double labelling of $\mathrm{P}_{2} \mathrm{Y}_{1}$ receptors (red) with $\mathrm{Ki}-$ 67 , a nuclear marker (green), to show that $\mathrm{P}_{2} \mathrm{Y}_{1}$ receptors are found in proliferating cells in the outer root sheath $(O R S)$ of the hair follicle. Scale bar $=50 \mu \mathrm{m}$. c Longitudinal section of anagen hair follicle through the dermal papilla $(D P)$ : double labelling of $\mathrm{P}_{2} \mathrm{Y}_{2}$ receptors (red) with proliferating cell nuclear antigen (PCNA), a marker for proliferating cells (green), showed that $\mathrm{P}_{2} \mathrm{Y}_{2}$ receptors were found in the cortex $(C T X)$ and at the edge of the medulla $(M)$ but not in the central medulla. $\mathrm{P}_{2} \mathrm{Y}_{2}$ receptors were not found in the matrix $(M a)$,
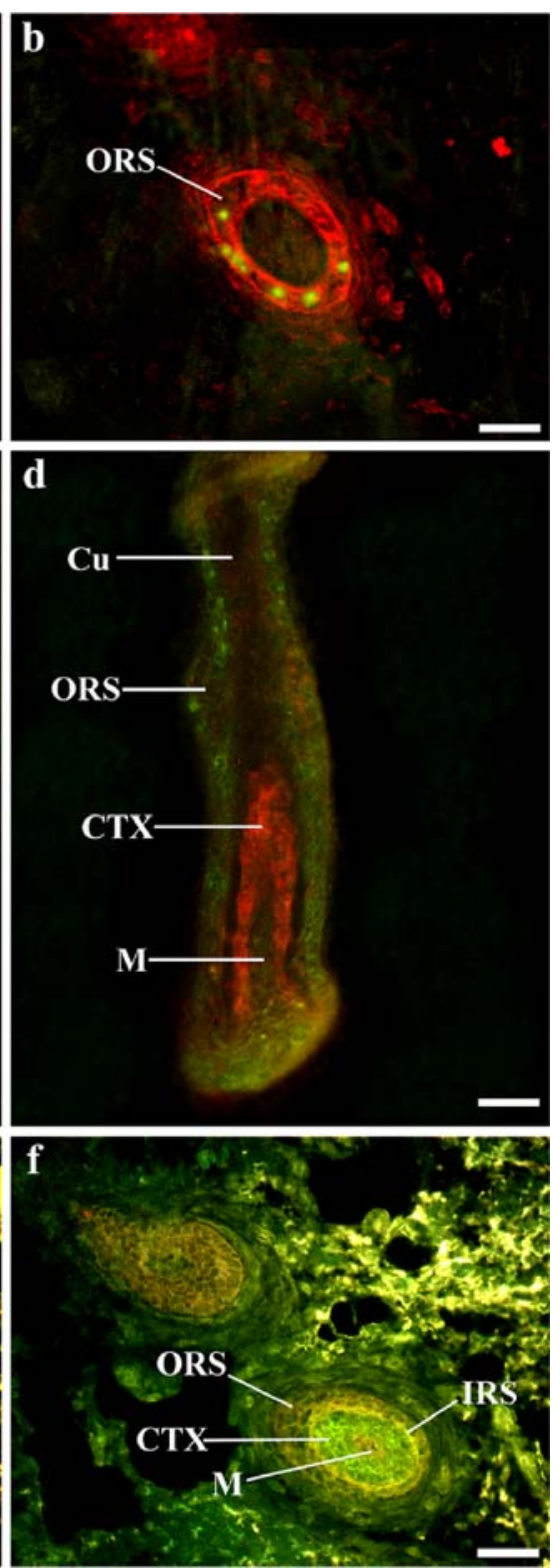

where cells were positive for PCNA. Scale bar=75 $\mu \mathrm{m}$. d Longitudinal section of anagen hair follicle: $\mathrm{P} 2 \mathrm{Y}_{2}$ receptors were absent from the keratinised cuticle $(\mathrm{Cu})$ of the hair shaft. PCNA was also found in cells of the outer root sheath $($ ORS $)$. Scale bar $=75 \mu \mathrm{m}$. e Double labelling of $\mathrm{P}_{2} \mathrm{X}_{5}$ receptors (red-brown) with involucrin, a marker for differentiating cells (green). Involucrin was expressed both in the inner root sheath (IRS), cortex (CTX) and in the outermost edge of the medulla $(M)$. $\mathrm{P} 2 \mathrm{X}_{5}$ receptors were expressed in the inner (IRS) and outer root sheaths $(O R S)$ and in the medulla $(M)$ and matrix cells $(M a)$. There was yellow colocalisation with $\mathrm{P}_{2} \mathrm{X}_{5}$ receptors in the inner root sheath and in cells at the outermost edge of the medulla (arrow). The cortex only stained positive for involucrin, not $\mathrm{P} 2 \mathrm{X}_{5}$ receptors. Scale bar $=50 \mu \mathrm{m}$. f Transverse section: double labelling of $\mathrm{P}_{2} \mathrm{X}_{5}$ receptors (red) with involucrin (green). Involucrin was expressed in the inner root sheath (IRS) and cortex (CTX) and colocalised (yellow) with $\mathrm{P}_{2} \mathrm{X}_{5}$ receptor staining in the inner root sheath (IRS). Scale bar $=50 \mu \mathrm{m}$ 
it is convenient to think of stem and transit-amplifying cells as discrete populations from fully differentiated keratinocytes, there might be gradients of cell behaviour, ranging from a cell that has maximum self-renewal and zero differentiation capacity to one that has completed terminal differentiation and cannot divide again. Transit-amplifying cells would lie in the middle of each gradient [1]. In anagen hair follicles, $\mathrm{P}_{2} \mathrm{Y}_{2}$ receptors are expressed on early differentiated hair keratinocytes that contribute to the formation of the hair shaft. Cells positive for $\mathrm{P}_{2} \mathrm{Y}_{2}$ receptors in hair follicles could still have some proliferative capacity given the right stimulus.

In anagen hair follicles, $\mathrm{P} 2 \mathrm{X}_{5}$ receptors were found on cells in the IRS, ORS and medulla. $\mathrm{P}_{2} \mathrm{X}_{5}$ receptors are expressed in the basal layer of the interfollicular epidermis but are expressed more strongly in the stratum spinosum and variably into the stratum granulosum [12]. The expression of $\mathrm{P} 2 \mathrm{X}_{5}$ receptors in the ORS was similar to that seen in the epidermis, with basal cells labelling less strongly than suprabasal cells. It has been proposed that $\mathrm{P} 2 \mathrm{X}_{5}$ receptors are involved in human epidermal keratinocyte differentiation $[10,12]$. There is evidence from other tissues regarding the role of $\mathrm{P}_{2} \mathrm{X}_{5}$ receptors. In foetal rat skeletal muscle, $\mathrm{P} 2 \mathrm{X}_{5}$ receptors are sequentially expressed during development [24] and associated with differentiating cells [25]. $\mathrm{P} 2 \mathrm{X}_{5}$ receptors have also been implicated in the regulation of osteoblastic differentiation and proliferation [26]. Involucrin is a marker of keratinocyte differentiation [27], which is found in the epidermis in the upper stratum spinosum and in the stratum granulosum. In the hair follicle, involucrin is expressed in the hair cortex, medulla, IRS and the innermost cells of the lower ORS [28]. Involucrin colocalised with $\mathrm{P} 2 \mathrm{X}_{5}$ receptor staining in the IRS and in a few cell layers at the edge of the medulla. This suggests a role for $\mathrm{P}_{2} \mathrm{X}_{5}$ receptors in the differentiation of cells of the medulla and IRS.

There was no staining with antibodies to $\mathrm{P} 2 \mathrm{X}_{7}$ receptors or active caspase-3 in the anagen hair follicle. Further work on the expression of $\mathrm{P}_{2} \mathrm{X}_{7}$ receptors in different stages of the hair cycle would be of interest. Periods of hair growth (anagen) are followed by a regression phase (catagen), when the lower part of the hair follicle undergoes programmed cell death [2], and a resting phase (telogen), before onset of a new growth phase. In this study, only hair follicles in the anagen phase were studied, as hair follicles in catagen or telogen phases of the hair cycle were not found in the sections analysed. At any one time, $84 \%$ of scalp hairs are in anagen, $2 \%$ in catagen and $14 \%$ in telogen [29]. The $\mathrm{P} 2 \mathrm{X}_{7}$ receptor is unlike other $\mathrm{P} 2 \mathrm{X}$ receptors because it is a bifunctional molecule that, in addition to forming a channel permeable to small cations, can be triggered to form a cytolytic pore permeable to large hydrophilic molecules up to 900 daltons [30]. The opening of this pore results in the increase in intracellular cytosolic free calcium ions and the induction of cell death $[31,32] . \mathrm{P}^{2} \mathrm{X}_{7}$ receptors are also found on dendritic cells, macrophages and microglial cells, where extracellular ATP can trigger apoptosis via these receptors. There is increasing evidence that this process is dependent on the caspase signalling cascade [33, 34]. It would be of interest to see whether $\mathrm{P} 2 \mathrm{X}_{7}$ receptors are involved in the process of programmed cell death that occurs during the catagen phase of the hair cycle.

In summary, P2 purinergic receptors are likely to be involved in ORS cell proliferation via $\mathrm{P}_{2} \mathrm{Y}_{1}$ receptors found in the bulb and ORS; IRS and medulla differentiation via activation of $\mathrm{P}_{2} \mathrm{X}_{5}$ receptors; and early differentiation of cells of the cortex and medulla of the hair shaft via activation of $\mathrm{P}_{2} \mathrm{Y}_{2}$ receptors. Expression of $\mathrm{P} 2$ purinergic receptors in the anagen hair follicle may have therapeutic implications for treating hair loss. The expression of P2 receptors in different cell lineages of the anagen hair follicle could provide the prospect of engineering hair follicles in those with hair loss or excess growth by using purinergic receptor agonists and antagonists. Lack of growth reflects follicular dynamics and represents the central mechanisms of most common causes of alopecia. In androgenetic alopecia, the hair-shaft diameter is reduced, and there is a progressive decrease in anagen hair percentage, as well as a significant reduction in proliferating cells [35]. The anagen phase is also shorter [36]. This results in the formation of progressively thinner and shorter hair. In some men, there is also prolongation of the interval between shedding of the club hair in telogen and the emergence of a replacement hair in the anagen phase, giving rise to an increase in the number of "empty" follicles [37]. Functional work on hair-follicle cycling, cell proliferation and differentiation using purinergic receptor agonists and antagonists may lead to new approaches in the treatment of hair loss.

Acknowledgements The support of Roche Bioscience, Palo Alto, CA, USA, who provided $\mathrm{P}_{2} \mathrm{X}_{5}$ and $\mathrm{P} 2 \mathrm{X}_{7}$ receptor antibodies, is gratefully acknowledged. Aina Greig is the recipient of a Research Fellowship from The Wellcome Trust and The Simpson Surgical Research Fellowship from The Royal College of Surgeons of England. The authors are grateful to Dr. Gillian E. Knight for editorial assistance.

\section{References}

1. Niemann C, Watt FM (2002) Designer skin: lineage commitment in postnatal epidermis. Trends Cell Biol 12:185-192

2. Cotsarelis G (1997) The hair follicle: dying for attention. Am J Pathol 151:1505-1509

3. Abbracchio MP, Burnstock G (1998) Purinergic signalling: pathophysiological roles. Jpn J Pharmacol 78:113-145

4. Burnstock G (2002) Purinergic signalling and vascular cell proliferation and death. Arterioscler Thromb Vasc Biol 22:364-373

5. Burnstock G (2007) Physiology and pathophysiology of purinergic neurotransmission. Physiol Rev 87:659-797 
6. Ralevic V, Burnstock G (1998) Receptors for purines and pyrimidines. Pharmacol Rev 50:413-492

7. Abbracchio MP, Burnstock G (1994) Purinoceptors: are there families of $\mathrm{P}_{2 \mathrm{X}}$ and $\mathrm{P}_{2 \mathrm{Y}}$ purinoceptors? Pharmacol Ther 64:445475

8. Gever J, Cockayne DA, Dillon MP et al (2006) Pharmacology of P2X channels. Pflugers Arch 452:513-537

9. Burnstock G (2007) Purine and pyrimidine receptors. Cell Mol Life Sci 64:1471-1483

10. Gröschel-Stewart U, Bardini M, Robson T et al (1999) Localisation of $\mathrm{P} 2 \mathrm{X}_{5}$ and $\mathrm{P} 2 \mathrm{X}_{7}$ receptors by immunohistochemistry in rat stratified squamous epithelia. Cell Tissue Res 296:599-605

11. Dixon CJ, Bowler WB, Littlewood-Evans A et al (1999) Regulation of epidermal homeostasis through $\mathrm{P}_{2} \mathrm{Y}_{2}$ receptors. $\mathrm{Br}$ J Pharmacol 127:1680-1686

12. Greig AVH, Linge C, Terenghi G et al (2003) Purinergic receptors are part of a functional signalling system for proliferation and differentiation of human epidermal keratinocytes. J Invest Dermatol 120:1007-1015

13. Oglesby IB, Lachnit WG, Burnstock G et al (1999) Subunit specificity of polyclonal antisera to the carboxy terminal regions of P2X receptors, $\mathrm{P}_{2} \mathrm{X}_{1}$ through $\mathrm{P}_{2} \mathrm{X}_{7}$. Drug Dev Res 47:189-195

14. Miyagawa S, Okada N, Takasaki Y et al (1989) Expression of proliferating cell nuclear antigen/cyclin in human keratinocytes. J Invest Dermatol 93:678-681

15. Eckert RL, Crish JF, Robinson NA (1997) The epidermal keratinocyte as a model for the study of gene regulation and cell differentiation. Physiol Rev 77:397-424

16. Gerdes J, Li L, Schlueter C et al (1991) Immunobiochemical and molecular biologic characterization of the cell proliferationassociated nuclear antigen that is defined by monoclonal antibody Ki-67. Am J Pathol 138:867-873

17. Tucci MG, Offidani A, Lucarini G et al (1998) Advances in the understanding of malignant transformation of keratinocytes: an immunohistochemical study. J Eur Acad Dermatol Venereol 10: $118-124$

18. Weil M, Raff MC, Braga VM (1999) Caspase activation in the terminal differentiation of human epidermal keratinocytes. Curr Biol 9:361-364

19. Llewellyn-Smith IJ, Song ZM, Costa M et al (1992) Ultrastructural localisation of nitric oxide synthase immunoreactivity in guinea-pig enteric neurons. Brain Res 577:337-342

20. Llewellyn-Smith IJ, Pilowsky P, Minson JB (1993) The tungstatestabilized tetramethylbenzidine reaction for light and electron microscopic immunocytochemistry and for revealing biocytinfilled neurons. J Neurosci Methods 46:27-40

21. Reynolds AJ, Jahoda CAB (1991) Hair follicle stem cells? A distinct germinative epidermal cell population is activated in vitro by the presence of hair dermal papilla cells. J Cell Sci 99:373385

22. Stenn KS, Paus R (2001) Controls of hair follicle cycling. Physiol Rev 81:449-494

23. Lee WK, Choi SW, Lee H-R et al (2001) Purinoceptor-mediated calcium mobilization and proliferation in $\mathrm{HaCaT}$ keratinocytes. $\mathrm{J}$ Dermatol Sci 25:97-105

24. Ryten M, Hoebertz A, Burnstock G (2001) Sequential expression of three receptor subtypes for extracellular ATP in developing rat skeletal muscle. Dev Dyn 221:331-341

25. Ryten M, Dunn PM, Neary JT et al (2002) ATP regulates the differentiation of mammalian skeletal muscle by activation of a P2 $\mathrm{X}_{5}$ receptor on satellite cells. J Cell Biol 158:345-355

26. Hoebertz A, Townsend-Nicholson A, Glass R et al (2000) Expression of $\mathrm{P} 2$ receptors in bone and cultured bone cells. Bone 27:503-510

27. Watt FM (1983) Involucrin and other markers of keratinocyte terminal differentiation. J Invest Dermatol 81:100s-103s

28. de Viragh PA, Huber M, Hohl D (1994) Involucrin mRNA is more abundant in human hair follicles than in normal epidermis. $\mathrm{J}$ Invest Dermatol 103:815-819

29. Dawber RPR (1991) The comparative physiology, embryology and physiology of human hair. In: Rook A, Dawber R (eds) Diseases of the hair and scalp. Blackwell Scientific Publications, Oxford, pp 1-17

30. Surprenant A, Rassendren F, Kawashima E et al (1996) The cytolytic $\mathrm{P}_{2 Z}$ receptor for extracellular ATP identified as a $\mathrm{P}_{2 \mathrm{X}}$ receptor $\left(\mathrm{P}_{2} \mathrm{X}_{7}\right)$. Science 272:735-738

31. Zheng LM, Zychlinsky A, Liu CC et al (1991) Extracellular ATP as a trigger for apoptosis or programmed cell death. J Cell Biol 112:279-288

32. Ferrari D, Villalba M, Chiozzi P et al (1996) Mouse microglial cells express a plasma membrane pore gated by extracellular ATP. J Immunol 156:1531-1539

33. Coutinho-Silva R, Persechini PM, Bisaggio RD et al (1999) P2Z/ $\mathrm{P}_{2} \mathrm{X}_{7}$ receptor-dependent apoptosis of dendritic cells. Am J Physiol 276:C1139-C1147

34. Ferrari D, Los M, Bauer MK et al (1999) P2Z purinoreceptor ligation induces activation of caspases with distinct roles in apoptotic and necrotic alterations of cell death. FEBS Lett 19:7175

35. Prieto VG, Sadick NS, Shea CR (2002) Androgenetic alopecia: analysis of proliferation and apoptosis. Arch Dermatol 138:11011102

36. Hoffmann R (2002) Male androgenetic alopecia. Clin Exp Dermatol 27:373-382

37. Courtois M, Loussouarn G, Hourseau C et al (1995) Ageing and hair cycles. Br J Dermatol 132:86-93 